\title{
Partial purification and characterization of chorionic gonadotrophin in plasma and in culture medium of trophoblast cells from the marmoset monkey (Callithrix jacchus)
}

\author{
P. T. K. Saunders*, P. M. Summers and J. P. Hearn \\ MRC/AFRC Comparative Physiology Research Group, Institute of Zoology, Regent's Park, \\ London NWI $4 R Y, U . K$.
}

\begin{abstract}
Summary. A biologically active gonadotrophin has been partly purified from the media of long-term cultures of trophoblast cells of the common marmoset monkey by a combination of precipitation and chromatography. Marmoset chorionic gonadotrophin (CG) is a glycoprotein which binds Concanavalin A and wheat germ agglutinin. The protein purified from culture media exists as several isoelectric species with $\mathrm{pI}$ in the range $\mathrm{pH} 3 \cdot 5-4.5$. On gel filtration it eluted with an apparent molecular weight of 68-72 000 but on PAGE migrated as if it was 58-65 000. A glycoprotein with similar characteristics has been recovered from plasma samples of pregnant marmosets. Biological activity of partly purified CG from media, as determined by a mouse testicular cell bioassay, was $1-3$ i.u./mg protein.
\end{abstract}

\section{Introduction}

The secretion of chorionic gonadotrophins (CG) by trophoblast cells is believed to be a critical event in the rescue of the corpus luteum, and the consequent maintenance of pregnancy, in primates (Knobil, 1973; Hearn, 1979; Peters et al., 1983). Bioassays and radioreceptor assays have been used successfully to detect $\mathrm{CG}$ in primates and to describe the different patterns of secretion during pregnancy in these species. Data from radioimmunoassays using a variety of antisera, some of which are specific for human $\mathrm{CG} \beta$-subunit, have inidcated that there are significant antigenic differences between the CGs of the primates with those of the apes showing the most homology with the man (see Hodgen, 1980, for review). However, as yet there are no comprehensive data on the biochemical characteristics of the $\mathrm{CG}$ of different primates.

Estimates for the time of first appearance of human CG in plasma range from 6 to 11 days after ovulation and therefore spans the time at which implantation occurs (Catt et al., 1975; Landesman \& Saxena, 1976; Ahmed \& Klopper, 1983; Hay, 1985). Human CG has been purified by several independent groups and has been the subject of intense investigation for many years. Chorionic gonadotrophin recovered from human pregnancy urine is reported to have a molecular weight $\left(M_{\mathrm{r}}\right)$ based on protein sequencing of 37000 (see Birken \& Canfield, 1980). The intact hormone has four $\mathrm{N}$-linked and four O-linked oligosaccharide side chains (Kessler et al., 1979a,b) and consists of two non-identical subunits designated alpha and beta (Morgan et al., 1974).

The aim of the current study was to purify and characterize the CG of the marmoset monkey. It is hoped that polyclonal and monoclonal antibodies raised against the marmoset CG will add to our understanding of the time of onset, and site of secretion of CG in the primate embryo during the critical peri-implantation period of development.

*Present address: Department of Obstetrics and Gynaecology, Centre for Reproductive Biology, 37 Chalmers Street, Edinburgh EH3 9EW, U.K. 


\section{Materials and Methods}

Samples. Marmosets were from the self-sustaining breeding colony housed at the Institute of Zoology under conditions reported previously (Hearn, 1983). Peripheral plasma samples were obtained on Days 25-55 of pregnancy. Trophoblast cells derived from marmoset embryos were established and cultured in Hams F10 medium with $20 \%$ (v/v) fetal calf serum and antibiotics as described by Summers et al. (1987). Unlabelled marmoset CG was purified from media pooled after $3-4$ days incubation and storage at $-20^{\circ} \mathrm{C}$.

Incubation of cells with radioactive amino acids and sugars. Marmoset trophoblast cells, typically established for 5-7 days after subculture, had formed vesicles of 2-4 mm surrounded by a small area of monolayer (see Summers $e t$ al., 1987). Medium was removed carefully and replaced with fresh medium which usually contained a reduced amount of fetal calf serum $(0-2.5 \% \mathrm{v} / \mathrm{v})$. Cells cultured with $20-30 \mu \mathrm{Ci}-\left[{ }^{35} \mathrm{~S}\right]$ methionine (sp act. $54.6 \mathrm{TBq} / \mathrm{mmol}$ ) were maintained in RPM 1 medium specifically depleted of methionine. Similarly, those incubated with $15-30 \mu \mathrm{Ci} \mathrm{L}-\left[4,5^{3} \mathrm{H}\right] \mathrm{leucine}$ (sp. act. $4.44 \mathrm{TBq} / \mathrm{mmol}$ ) were usually maintained in leucine-free Medium RPMI although in initial experiments leucine was added to cells cultured in Hams F10 with FCS. In a few cases $2-10 \mu \mathrm{Ci} \mathrm{D}-\left[\mathrm{U}^{14} \mathrm{C}\right]$ glucosamine hydrochloride (sp. act. $11.4 \mathrm{GBq} / \mathrm{mmol}$ ) were added to cultures containing labelled leucine. All media were supplied by Flow Laboratories, Paisley, U.K., and radiolabelled materials were supplied by Amersham International plc, Amersham, Bucks, U.K. Samples for determination of radioactivity were mixed with $4 \mathrm{ml}$ Insta-gel (Packard Instrument Br Chemical Operations, Groningen, Netherlands) and counted in a liquid scintillation spectrometer (Packard Instruments). Chemicals were all reagent grade or better and were supplied by BDH Chemicals Ltd, Poole, U.K.

Determination of $C G$ biological activity and protein content. Gonadotrophin activity in samples before and after purification was determined using the mouse Leydig cell bioassay (Van Damme et al., 1974) with the modifications described by Harlow et al. (1984). The standard used was the second international reference preparation of human pituitary gonadotrophin (WHO 78/549). Samples of medium containing FCS and those incubated with blastocysts on Days 8-10 had no CG-like activity in the assay (P. M. Summers, unpublished observations). Estimates of protein content were made by determination of absorbance at $280 \mathrm{~nm}$ compared to a standard of bovine serum albumin.

Recovery of gonadotophin from culture media and plasma. Media from trophoblast cultures, or plasmas from pregnant marmosets, were pooled and their volume determined; plasma samples were diluted to $5 \mathrm{ml}$ with phosphatebuffered saline (PBS, $\mathrm{pH}$ 7.4). An aliquant was taken for determination of $\mathrm{CG}$ and protein content before the addition of $0.02 \%(\mathrm{w} / \mathrm{v})$ sodium azide and phenylmethylsulphonyl fluoride (PMSF, $0.1 \mathrm{mM}$ ). Saturated ammonium sulphate was added to a final concentration of $60 \%(\mathrm{v} / \mathrm{v})$, the solutions were mixed and left at $4^{\circ} \mathrm{C}$ for $1 \mathrm{~h}$. The mixture was centrifuged at $4500 \mathrm{~g}$ for $30-45 \mathrm{~min}$, the supernatant was removed, the pellet dissolved in PBS and precipitation was repeated using $50 \%$ saturated ammonium sulphate. Proteins recovered in the second precipitate were dissolved in PBS, usually to less than the original volume of the sample. When incubations were performed using media with radiolabelled precursors and from which serum was omitted, precipitation was not always carried out and unincorporated label was removed by dialysis against PBS $(2 \times 2$ litres $)$ before gel filtration.

Gel filtration chromatography. Samples $(2-3 \mathrm{ml})$ of proteins precipitated from medium or plasma using saturated

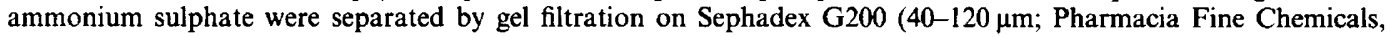
Uppsala, Sweden). Columns $(1.6 \times 100 \mathrm{~cm} ; 2 \times 112 \mathrm{~cm})$ run in PBS with $0.15 \mathrm{M}-\mathrm{NaCl}, 0.02 \%$ sodium azide, $0.1 \mathrm{mM} \cdot \mathrm{PMSF}$ and were calibrated using a mixture of protein standards (bovine $\mathrm{IgG}, M_{\mathrm{r}} 120000$; human transferrin, $M_{\mathrm{r}} 78000$; bovine serum albumin, $M_{\mathrm{r}} 66000$; ovalbumin, $M_{\mathrm{r}} 45000$; ribonuclease A, $M_{\mathrm{r}} 137000$; all supplied by Sigma Chemical Co, Poole, U.K.). Void volume was determined using dextran blue, and fractions of $2-3 \cdot 1 \mathrm{ml}$ were collected.

Affinity chromatography. Proteins eluting from G200 with apparent molecular weights in the range of 50-95000 were pooled and dialysed against $50 \mathrm{~mm}$-sodium acetate buffer, $\mathrm{pH} \mathrm{6.8.} \mathrm{Glycoproteins} \mathrm{containing} N$-linked oligosaccharide chains (see Baenziger \& Fiete, 1979) were isolated by chromatography on columns (5-10 ml) of Concanavalin A agarose (Con A agarose; Sigma Chemical Co Ltd) equilibrated with 50 mM-sodium acetate buffer, pH 6.8, 0.15 $\mathrm{M}-\mathrm{NaCl}, 1 \mathrm{~mm}-\mathrm{MnCl}_{2}, 1 \mathrm{mM}-\mathrm{CaCl}_{2}$. Bound glycoprotein was eluted by washing with buffer containing $100 \mathrm{~mm}$-alphamethyl D-glucoside or $500 \mathrm{mM}$-alpha-methyl mannoside and by $0.2 \mathrm{M}$-acetic acid.

Chromatofocussing was carried out on PBE 94 (Pharmacia Fine Chemicals) according to the manufacturer's instructions. Briefly, the gel was packed into a column $(1 \times 50 \mathrm{~cm})$ and equilibrated with $0.025 \mathrm{M}$-histidine- $\mathrm{HCl} \mathrm{pH}$ 6.2. The salt content of samples was reduced by dialysis against histidine buffer ( $2 \times 2$ litres). Proteins were eluted by a gradient ( $\mathrm{pH} 6 \cdot 2-4)$ generated by the application of 9 column volumes of degassed polybuffer $74-\mathrm{HCl}$ (diluted 1:8 with distilled water, adjusted $\mathrm{pH} 4$ ).

Polyacrylamide gel electrophoresis ( $P A G E$ ). Gels for both one- and two-dimensional electrophoresis were prepared according to the methods of Roberts et al. (1984); reagents were electrophoretic grade from BDH Chemicals Ltd, Poole, U.K. Samples for one-dimensional gels were mixed (1:1) with sodium dodecyl sulphate (SDS) buffer ( $25 \mathrm{~mm}$ Tris-acetate $\mathrm{pH} 6.8,2 \%(\mathrm{w} / \mathrm{v})$ SDS, $20 \%(\mathrm{v} / \mathrm{v})$ glycerol, and $2 \%(\mathrm{v} / \mathrm{v}) \beta$-mercaptoethanol containing bromophenol blue. Those for two-dimensional electrophoresis were dissolved in $9.5 \mathrm{M}$-urea with $2 \%(\mathrm{v} / \mathrm{v})$ Nonidet $40,2 \%(\mathrm{v} / \mathrm{v})$ ampholines (pH 3-10) and 5\% (v/v) $\beta$-mercaptoethanol. Slab gels contained $7.5,10$ or $12.5 \%(\mathrm{w} / \mathrm{v})$ acrylamide and $0.1 \%(w / v)$ SDS proteins were separated at $20-30 \mathrm{~mA} / \mathrm{gel}$ in a vertical electrophoresis unit (LKB-Produkter AB, Bromma, Sweden). Gels were stained with Coomassie blue. Gels used to separate radioactive samples were cut into 2-mm slices and incubated with NCS solubilizer (Packard Instrument Co., Groningen, Switzerland) for $16 \mathrm{~h}$ before 
mixing with scintillation fluid (Instagel, Packard). Before autoradiography gels were soaked for 15-30 min in Amplify (Amersham) and dried under vacuum onto 3MM chromatography paper (Whatman Ltd, Maidstone, Kent) using a Bio-Rad gel drier set at $60^{\circ} \mathrm{C}$. Gels were placed in X-ray cassettes with XAR-5 film (Kodak, Rochester, NY, U.S.A.) at $-70^{\circ} \mathrm{C}$ for $3-7$ days.

Electroblotting and localization with lectins. After PAGE gels were equilibrated with transfer buffer (12 $\mathrm{g}$ Tris, $57.65 \mathrm{~g}$ glycine, 1 litre methanol made up to 5 litres with distilled water) for $30 \mathrm{~min}$. Proteins were transferred onto nitrocellulose paper $(0.45 \mu \mathrm{m}$; Schleicher \& Schull, West Germany) by applying a current of $85 \mathrm{~mA}$ for $6 \mathrm{~h}$. Nitrocellulose papers were soaked in PBS containing $0.05 \%(\mathrm{v} / \mathrm{v})$ Tween 20 for $1 \mathrm{~h}$ before incubation in PBS containing peroxidase-conjugated lectins (Sigma) from Triticum vulgaris (wheat germ) or Concanavalin A (jack bean) for $16 \mathrm{~h}$ at $4^{\circ} \mathrm{C}$. Peroxidase was visualized by incubation of blots in $0.002 \%(\mathrm{w} / \mathrm{v}) 3,3^{\prime}$-diaminobenzidine tetrahydrochloride in 50 mM-Tris- $\mathrm{HCl}$ (pH 7.6, $50 \mathrm{ml}$ ) to which had been added $30 \mu l$ hydrogen peroxide ( $30 \%$ solution).

Isoelectric focussing (IEF). Proteins were separated according to their isoelectric point in acrylamide gels using the LKB flat bed multiphor system according to the manufacturer's instructions. Briefly, acrylamide gels ( $5 \%$ ( $/ \mathrm{v}$ ) acrylamide/bis-acrylamide) containing ampholines with $\mathrm{pI}$ in the range $\mathrm{pH} 3-10.5$ (final concentration $2 \% \mathrm{v} / \mathrm{v}$; Pharmacia Fine Chemicals) were cast between glass plates $(260 \times 124 \times 1 \mathrm{~mm})$ sealed with a rubber spacer $(1.5 \mathrm{~mm}$ thick). Electrode strips were soaked in $1 \mathrm{M}$-orthophosphoric acid (anode) or $1 \mathrm{M}$-sodium hydroxide (cathode). Samples were applied using 3MM paper (Whatman); the papers were removed after $0.5-1 \mathrm{~h}$. Separation was achieved by applying a power of $25 \mathrm{~W}$ for $1.5-2 \mathrm{~h}$, during which time voltage changed from 0.5 to $2 \mathrm{kV}$ and current decreased from 30 to $8 \mathrm{~mA}$. Proteins were fixed in a solution containing $0.704 \mathrm{M}$-trichloracetic acid and $0 \cdot 136 \mathrm{M}$-sulphosalicylic acid and stained with Coomassie blue.

Gonadotrophin purified from culture media was incubated in sodium acetate buffer $(50 \mathrm{~mm} \mathrm{pH} 5 \cdot 1)$ with neuraminidase (type X-A) immobilized on beaded agarose $\left(0.9 \mathrm{U} / \mathrm{ml}\right.$ gel; Sigma) for $16 \mathrm{~h}$ at $37^{\circ} \mathrm{C}$.

\section{Results}

\section{Purification}

Marmoset CG was recovered from pooled culture media and from the plasmas of pregnant marmosets by a combination of precipitation and chromatography (Table 1). About $50-70 \%$ of available CG was precipitated with $50 \%$ saturated ammonium sulphate. The G200 elution profiles of proteins precipitated from media containing $\left[{ }^{3} \mathrm{H}\right]$ leucine are illustrated in Fig. 1. In medium and

Table 1. Partial purification of marmoset CG from medium (including FCS) or plasma

\begin{tabular}{|c|c|c|c|c|c|}
\hline Sample/column & $\begin{array}{l}\text { CG activity* } \\
\text { (mi.u./ml pooled } \\
\text { sample) }\end{array}$ & $\begin{array}{c}\text { Protein } \dagger \\
\text { (mg/ml pooled } \\
\text { sample) }\end{array}$ & $\begin{array}{c}\text { Specific } \\
\text { activity } \\
\text { (mi.u./mg protein) }\end{array}$ & $\begin{array}{l}\text { Total CG in pooled } \\
\text { sample (recovery) } \\
\text { (i.u.) }\end{array}$ & $\begin{array}{l}\text { Purification } \\
\text { factor }\end{array}$ \\
\hline \multicolumn{6}{|l|}{ (A) Medium } \\
\hline Pooled medium & 1900 & $12 \cdot 2$ & $155 \cdot 7$ & 140 & - \\
\hline Precipitate $\ddagger$ & 5100 & $17 \cdot 5$ & $291 \cdot 4$ & $\begin{array}{c}102 \\
(72 \cdot 5 \%)\end{array}$ & 1.9 \\
\hline $\begin{array}{l}\mathrm{G} 200(3.5 \mathrm{ml} \\
\text { precipitate loaded })\end{array}$ & 238 & 0.38 & 626 & $\begin{array}{c}10.6 \\
\text { (17.8 loaded) }\end{array}$ & 4 \\
\hline Con $A \S$ & 136 & 0.05 & 2720 & 2.53 & $17 \cdot 5$ \\
\hline \multicolumn{6}{|l|}{ (B) Plasma } \\
\hline Precipitate & 592 & $18 \cdot 3$ & $32 \cdot 3$ & $\begin{array}{c}1 \cdot 8 \\
(54 \cdot 1 \%)\end{array}$ & 3 \\
\hline G200 (2 ml precipitate) & 25 & 0.39 & $64 \cdot 1$ & $\begin{array}{c}1 \cdot 1 \\
(1.2 \text { loaded })\end{array}$ & 6 \\
\hline $\begin{array}{l}\text { Con } A \& \text { (mean of } \\
2 \text { columns) }\end{array}$ & $17 \cdot 8$ & 0.1 & 105 & 0.3 & 9.9 \\
\hline
\end{tabular}

*Mouse Leydig cell bioassay.

†Determined by absorbance $280 \mathrm{~nm}$, BSA standards.

†Precipitate dissolved in smaller volume than original sample.

$\S$ Activity in fractions eluted by $\alpha$-methylglucoside only. 
plasma samples gonadotrophic activity was detected in fractions of the eluate containing proteins eluting with apparent $M_{\mathrm{r}}$ of $65-75000$. A sample of ${ }^{125}$ I-labelled human CG mixed with an unlabelled sample of marmoset CG eluted with an apparent $M_{\mathrm{r}}$ of about 70000 . In samples from radiolabelled culture media, radioactivity and $C G$ activity were detectable in eluates containing protein(s) with slightly higher $M_{\mathrm{r}}(80-10000)$ but the specific activity of these fractions (200 mi.u/mg) was 5-10-fold lower than that of the protein(s) with $M_{\mathrm{r}} 60-80000$. PAGE (see Fig. 3 ), revealed that most of the albumin in the culture medium was not precipitated by $50 \%$ saturated ammonium sulphate.

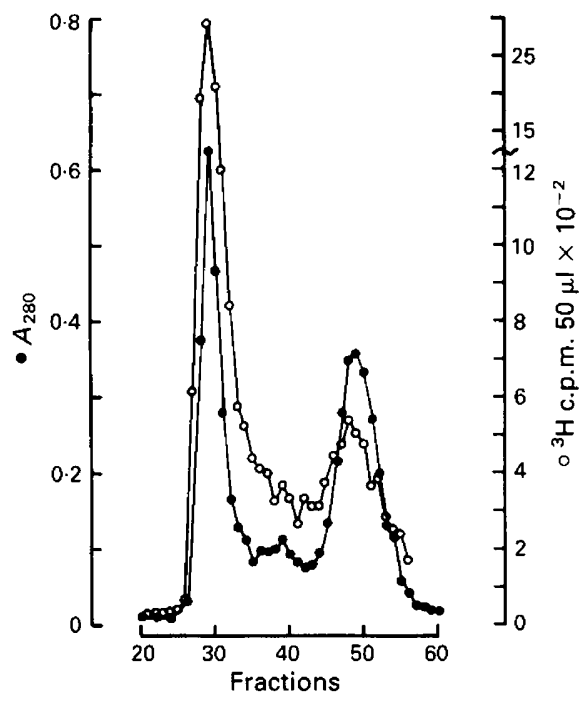

Fig. 1. Gel filtration of proteins precipitated by saturated ammonium sulphate from culture medium of cells incubated for $72 \mathrm{~h}$ in Hams F10 medium with $20 \% \mathrm{FCS}$ and $50 \mu \mathrm{Ci}\left[{ }^{3} \mathrm{H}\right]$ leucine/ $\mathrm{ml}$. Radioactivity $(0.15 \mathrm{ml})$ and absorbance at $280 \mathrm{~nm}$ of fractions $(2.1 \mathrm{ml})$ were measured. Proteins with apparent $M_{\mathrm{r}} 92-47000$ (fractions 45-55) were pooled: CG content of the pool was $260 \mathrm{~m}$ i.u. $/ \mathrm{ml}$ (total 6 i.u.).

Additional purification of $\mathrm{CG}$ was achieved by affinity chromatography using Con $\mathrm{A}$ and at least $70 \%$ of biologically active CG recovered after elution from G200 was bound by the Con A lectin. The glycoprotein was eluted with alpha methylglucoside (Fig. 2). Gel filtration was found to be a necessary preliminary to affinity chromatography to avoid contamination of CG-containing fractions with high molecular weight proteins eluting in the void volume of G200. The specific activity of the CG isolated after Con A chromatography was increased 10-20-fold relative to that in pooled culture media or plasma (Table 1). The biological activity of CG purified from plasma (60$120 \mathrm{mi} . \mathrm{u} . / \mathrm{mg}$ ) was always lower than that present in the media isolated from cultures of trophoblast cells (up to $4 \cdot 5$ i.u./mg).

\section{Polyacrylamide gel electrophoresis}

Samples were taken at each stage of purification and the constitutent proteins were visualized by staining gels with Coomassie blue after one-dimensional PAGE (Fig. 3). After mixing with saturated ammonium sulphate and centrifugation, most serum albumin in the culture media remained in the supernatant (Fig. 3, lanes 1,2). The precipitate (lane 3) contained a number of high molecular weight proteins which did not enter the $10 \%$ acrylamide gel and these eluted from G200 with an apparent $M_{\mathrm{r}}$ of $>250000$ (lane 4). Pooled eluates from G200 containing CG activity migrated as a broad, diffusely stained band with $M_{\mathrm{r}}$ in the range 58-78000 (lane 5). In unpurified 


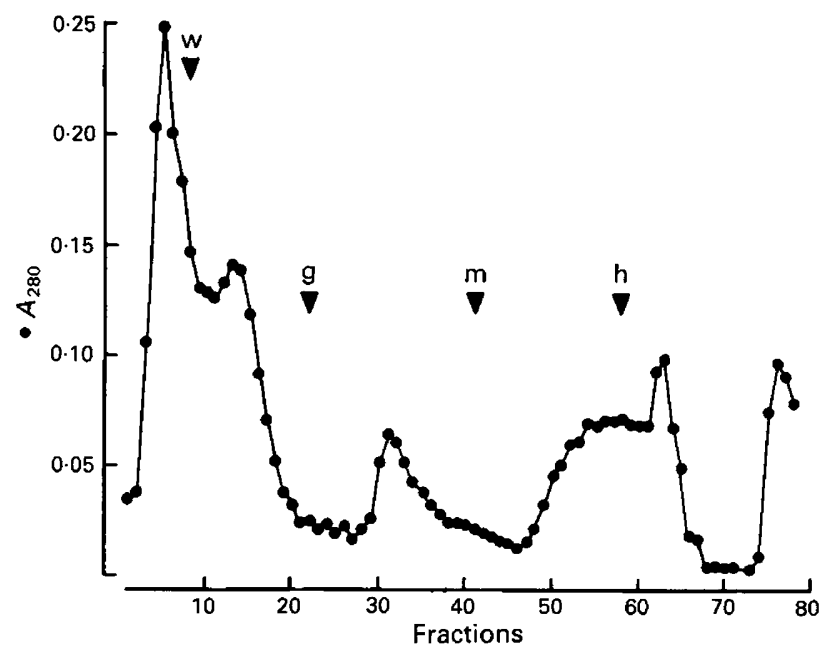

Fig. 2. Concanavalin A (Con A) affinity chromatography of proteins recovered from plasma by ammonium sulphate precipitation and gel filtration (see Fig. 1). CG-containing fractions were separated on Con A-agarose $(1 \times 5 \mathrm{~cm})$ equilibrated with 20 mM-acetate buffer pH 6.8 $\left(0 \cdot 15 \mathrm{M}-\mathrm{NaCl}, 1 \mathrm{~mm}-\mathrm{MnCl}_{2}, 1 \mathrm{~mm}-\mathrm{CaCl}_{2}\right.$, azide). After washing with buffer (w) bound proteins were eluted by sequential application of buffer containing $100 \mathrm{~mm}-\alpha$-methylglucoside $(\mathrm{g})$, $500 \mathrm{~mm}-\alpha$-methylmannoside (m) and by $0.2 \mathrm{M}$-acetic acid (h). Fractions 29-35 contained biologically active CG $(6.4 \mathrm{mi} . \mathrm{u} . / \mathrm{ml} ; 91.4 \mathrm{mi} . \mathrm{u} . / \mathrm{mg}$ protein $)$.

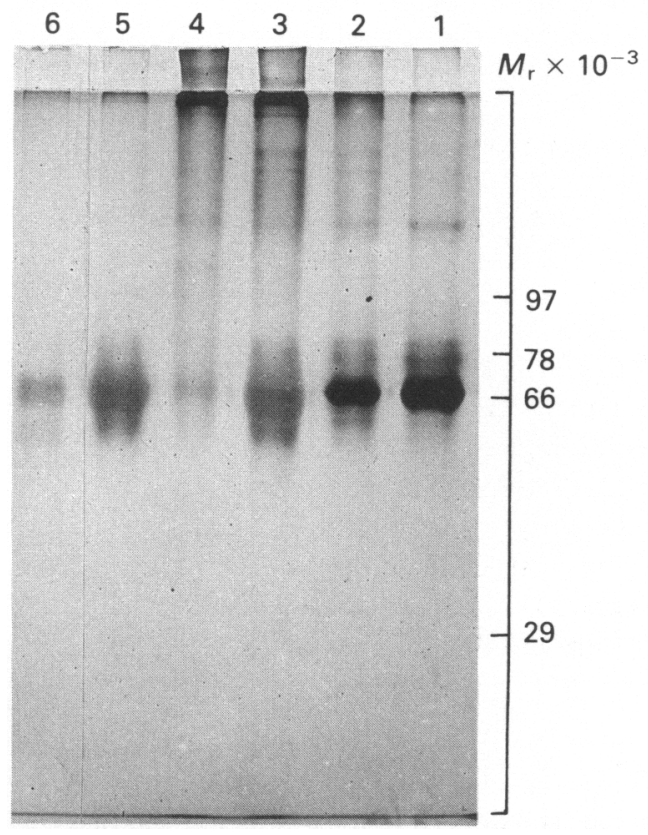

Fig. 3. SDS polyacrylamide gel electrophoresis of samples taken at each step of purification of CG. Gels were stained with Coomassie brilliant blue; the $M_{\mathrm{r}}$ values of standards are shown. Lanes 1 and 2 , proteins remaining in the supernatant after precipitation with ammonium sulphate and centrifugation at $4500 \mathrm{~g}$; lane 3 , proteins precipitated by $50 \%$ ammonium sulphate; lanes 4 and 5 , pooled fractions from G200 after separation of a sample of precipitate (lane 4, apparent $M_{\mathrm{s}}$ $>300000$, lane 5, apparent $M_{\mathrm{r}} 50-80000$ ); lane 6, sample as for lane 5, applied to Con A sepharose and eluted with alpha-methylglucoside. 
samples it was impossible to distinguish CG from serum albumin unless the gels were stained with Schiff's reagent which is specific for glycoproteins (not shown). Glycoproteins were isolated from pooled G200 eluates using Con A agarose. Biological CG activity was associated with proteins bound to Con A; these proteins migrated on PAGE with apparent $M_{\mathrm{r}} 60-64000$ (lane 6).

When gels containing radiolabelled samples were sliced, radioactivity was associated with the stained area of the gel with an apparent $M_{\mathrm{r}}$ of 62000 . Autoradiography of ${ }^{35} \mathrm{~S}$-labelled proteins (Fig. 4) revealed more radiolabelled species than were detected by slicing the gels. These included protein(s) with apparent $M_{\mathrm{r}}(65-80000)$ greater than the most abundant radiolabelled species $\left(M_{\mathrm{r}}\right.$ 62-64000) and two bands at about $M_{\mathrm{r}} 35000$ and 32000 . On some autoradiographs a faint band was also detectable at $M_{\mathrm{r}} 22000$. On two-dimensional PAGE purified CG was detected as a broad stained band at the acidic side of the gel, pI $<4.5$ (not shown). It was not possible to identify distinct isoelectric species of the $\mathrm{CG}$ using this technique. After PAGE proteins were transferred to nitrocellulose and incubated with peroxidase-conjugated WGA or Con A lectins. Proteins in pooled eluates from G200 identified by autoradiography were also stained by both lectins. The most heavily stained band in G200 and Con A eluates had an apparent $M_{\mathrm{r}}$ of 62-64000 (not shown).

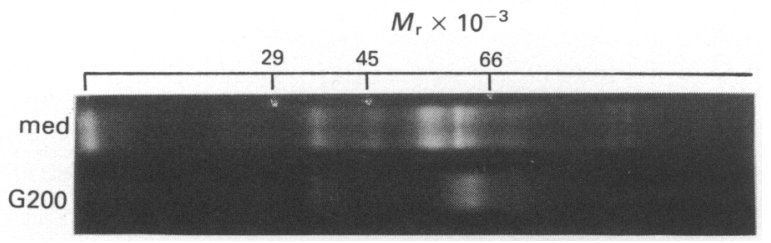

Fig. 4. Autoradiography of proteins isolated from media of cells incubated with $\left[{ }^{35} \mathrm{~S}\right]$ methionine separated by PAGE (see Fig. 3), the dried gel was exposed to XAR-5 film for 3 days. Lanes contained samples of dialysed medium (med) and pooled CG-containing fractions from G200.

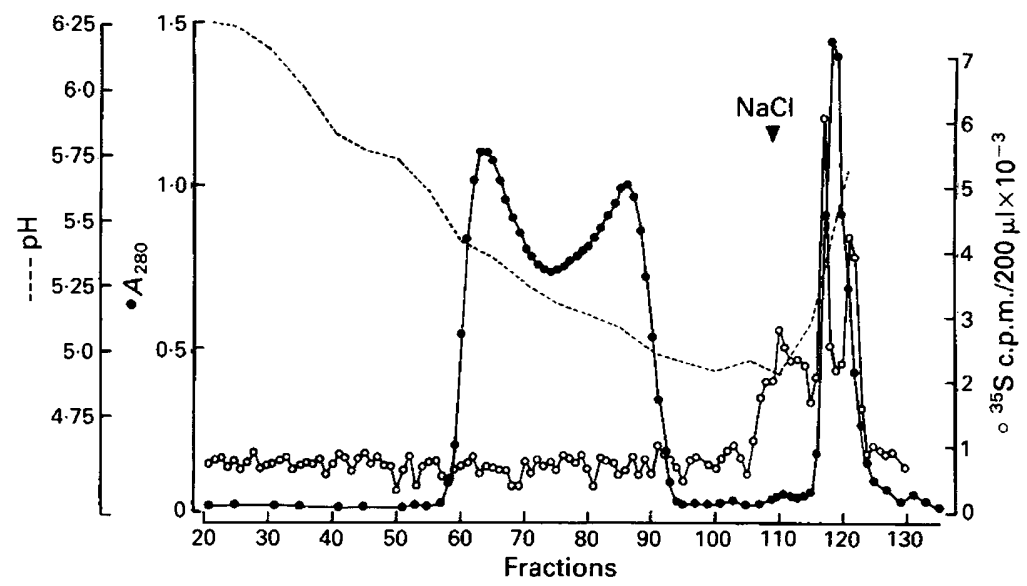

Fig. 5. Determination of the isolelectric point of radiolabelled $\left({ }^{35} \mathrm{~S}\right) \mathrm{CG}$-containing fractions pooled from G200 (see Fig. 1) by chromatofocussing on PBE 94. Unlabelled proteins precipitated from culture media by ammonium sulphate were added as carrier. The sample and PBE were equilibrated with $0.025 \mathrm{M}$-histidine- $\mathrm{HCl} \mathrm{pH} \mathrm{6.2.} \mathrm{After} \mathrm{sample} \mathrm{application} \mathrm{the} \mathrm{column} \mathrm{was}$ washed and no protein or radioactivity was detected in the eluate (not shown). Bound proteins were eluted with dilute polybuffer $74 \mathrm{pH} 4$; tightly bound proteins $(\mathrm{pI}<4 \cdot 5$ ) were eluted with $1 \mathrm{M}-\mathrm{NaCl}, 1 \cdot 5-\mathrm{ml}$ fractions were collected. Aliquants $(0.2 \mathrm{ml})$ were removed for determination of radioactivity, $\mathrm{pH}$ was determined with an electrode, absorbance was measured at $280 \mathrm{~nm}$. Biological CG activity was only detected in a pool of fractions 116-124 (60.3 mi.u./ml). 


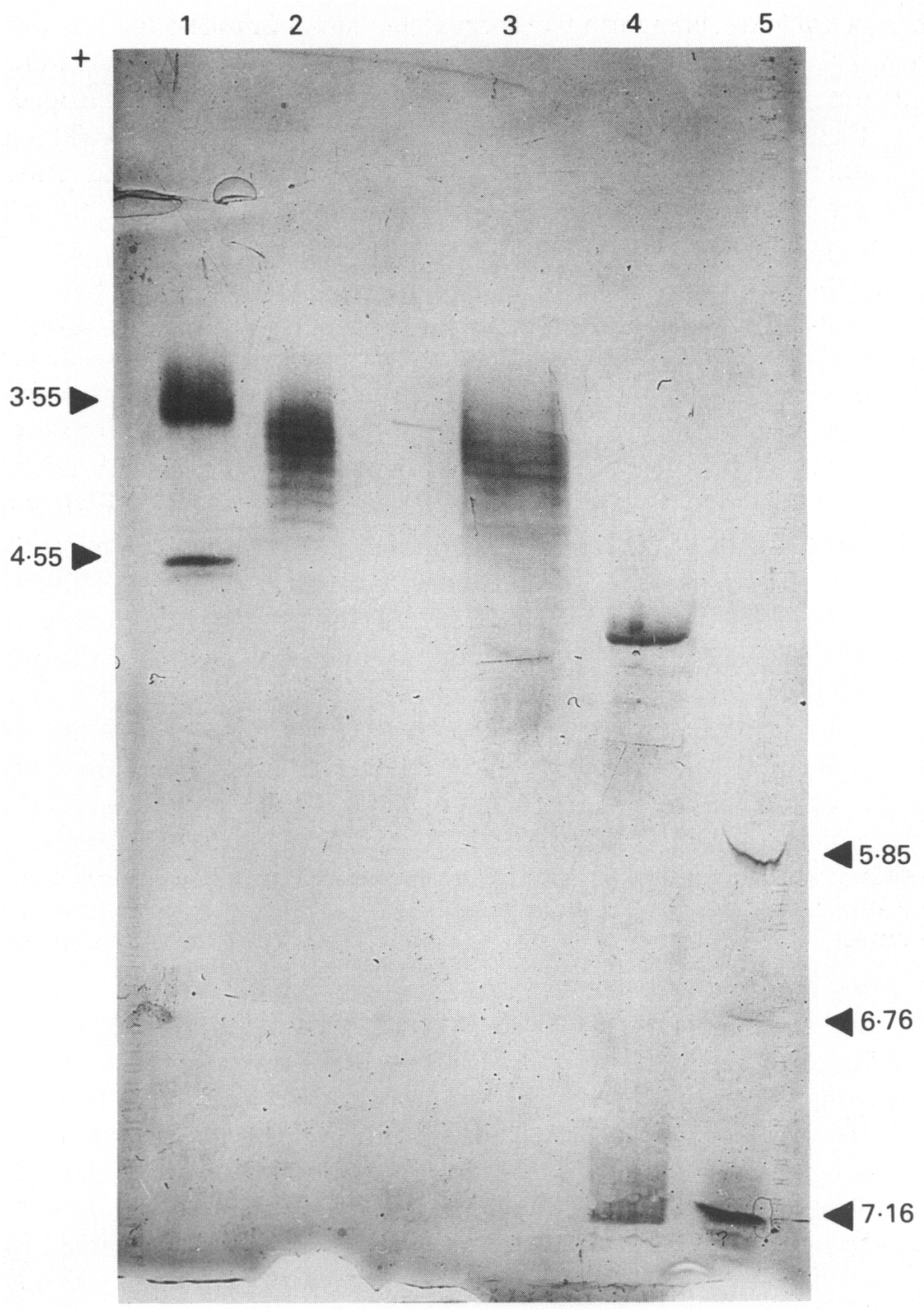

Fig. 6. Separation of different isoelectric species of CG by isoelectric focussing in an acrylamide gel containing ampholines of $\mathrm{pH}$ range 2.5-7.0. Lane 1, standards: amylglucosidase pI $3 \cdot 55$, trypsin inhibitor pI 4.55 ; lane 2, CG purified by precipitation and gel filtration; lane 3 , proteins precipitated from culture media with $60 \%$ ammonium sulphate; lane 4 , proteins, precipitated from plasmas of pregnant marmosets; lane 5, standards: carbonic anhydrase pI 5.85, myoglobin pI 6.76 and $7 \cdot 16$. Gels were fixed and then stained with Coomassie brilliant blue.

\section{Chromatofocussing}

Partly purified radiolabelled CG and unlabelled proteins precipitated from culture media were separated according to their isoelectric points by chromatofocussing (Fig. 5). Radioactivity and CG biological activity were detected in fractions containing protein(s) which bound tightly to the PBE74 at pH $6 \cdot 2$, had a pI $<4 \cdot 7$, and were only eluted from the gel by $1 \mathrm{M}-\mathrm{NaCl}$. 


\section{Isoelectric focussing (IEF)}

Seven isoelectric variants were clearly distinguishable in samples containing partly purified CG from media (Fig. 6, lane 2). Their pIs ranged from pH 3.5-4.5; those with $\mathrm{pI}$ of $3 \cdot 65,3 \cdot 76$ and $3 \cdot 8$ were the most abundant in the sample illustrated. In a single experiment, an IEF gel was processed for autoradiography in the same way as those from PAGE and it was confirmed that the major isoelectric species in the partly purified CG were radioactive. Gonadotrophin isolated from plasmas was also separated into several isoelectric variants with $\mathrm{pI}$ in a similar $\mathrm{pH}$ range (not visible on Fig. 6). Incubation of partly purified CG from culture medium with neuraminidase resulted in a shift in $\mathrm{pI}$ of the glycoprotein to a higher $\mathrm{pH}(5 \cdot 4-5 \cdot 6)$ and a decrease in the number of observed bands from 5-8 to $2-3$ depending on the preparation.

\section{Discussion}

In this paper we report the partial purification and characterization of the gonadotrophin secreted in vitro by the trophoblast cells of the common marmoset monkey. Previous papers have reported the presence of gonadotrophic activity in the serum (Chambers \& Hearn, 1979; Harlow et al., 1984), term placenta (Hobson \& Wide, 1972) and urine (Hodgen et al., 1976) of marmosets. Since marmosets are small $(300-450 \mathrm{~g})$ and live in family groups, it was not practical to purify large amounts of CG from plasma or urine. A small amount of CG was recovered from the plasma of pregnant marmosets by using the technique developed to recover $\mathrm{CG}$ from culture fluids, and this appeared to have an $M_{\mathrm{r}}$ similar to that of $\mathrm{CG}$ secreted by trophoblast cells in vitro. The time course of CG secretion in apes and monkeys has been described (Hodgen, 1980) but as yet there have been few reports of attempts to purify CGs from the tissues and fluids of the smaller primates.

The CG recovered from trophoblast cell culture media is a glycoprotein and after PAGE and transfer to nitrocellulose paper it was stained by peroxidase-labelled Con A or wheat germ lectins. During Con A affinity chromatography of samples after gel filtration, $>70 \%$ of the CG biological activity eluted from the column was recovered in the 'bound' fraction eluted with alphamethylglucoside. In other experiments about $30-50 \%$ of the CG was bound by immobilized WGA (P.T.K. Saunders, unpublished observations). These results are consistent with most of the CG polypeptides possessing oligosaccharide chain(s) of the 'complex' type with a trimannose core that are attached to the protein backbone via $N$-glycosidic linkages (Cummings \& Kornfeld, 1982).

Chromatofocussing, two-dimensional PAGE and IEF demonstrated that partly purified marmoset $\mathrm{CG}$ recovered from media has multiple pIs in the range $\mathrm{pH} 3 \cdot 5-4 \cdot 5$. Many glycoproteins exist as multiple isoelectric species due to variations in the numbers of charged sugars in their oligosaccharide chain(s); when the samples were incubated with neuraminidase a shift in the pI occurred which would be consistent with the removal of sialic acid.

On G200 marmoset CG, identified by bioassay, eluted with an apparent $M_{\mathrm{r}}$ similar to that of iodinated human $\mathrm{CG}$, with most activity being recovered in pooled eluates containing proteins with apparent $M_{\mathrm{r}}$ 55-80000. However, some CG activity was also found in fractions containing (glyco)proteins with $M_{\mathrm{r}} 80-10000$. On PAGE, the bulk of the radiolabelled partly purified marmoset CG had an apparent $M_{\mathrm{r}} 62-64000$ although some radioactivity was also associated with glycoproteins with $M_{\mathrm{r}} 66-80000$. Under the conditions used a standard undissociated human CG migrated with $M_{\mathrm{r}} 60000$; other groups have reported the migration of intact hCG on PAGE with $M_{\mathrm{r}} 58000$ (Birken \& Canfield, 1980; Maruo et al., 1980). Unlike a standard sample of human CG, unlabelled marmoset $\mathrm{CG}$ isolated from trophoblast culture media did not readily dissociate into subunits when boiled in the presence of $\beta$-mercaptoethanol and SDS (P. T. K. Saunders, unpublished observations). However, after fluorography of ${ }^{35}$ S-labelled samples, bands with apparent $M_{\mathrm{r}} 35000$ and 32000 were detected. Beta subunits of hCG have been reported to migrate in acrylamide gels with $M_{\mathrm{r}}$ in the range 28-36000 (Canfield \& Morgan, 1973; Canfield et al., 1971; Maruo et al., 1980) and the low molecular weight bands might therefore be two forms of the $\beta$-subunit of marmoset CG. Unfortunately, insufficient partly purified radiolabelled $C G$ was available to allow for dissociation 
into subunits with urea or guanidine $\mathrm{HCl}$ to determine the size of subunits and confirm the speculations based on the preliminary findings obtained using PAGE.

The isolation of 'high molecular weight species' of human CG with additional sugar moieties from cultures of human placenta (Maruo et al., 1980) has been reported. Glycosylation may also be altered by the conditions of culture (Warren et al., 1982) and it has been reported that cultured trophoblast cells accumulate intracellular subunit forms of hCG with incompletely processed oligosaccaride chains (Peters et al., 1983). Additional purification and data on the size of the oligosaccharides in marmoset $\mathrm{CG}$ and any differences between those of the CG secreted in vitro and that recovered from plasma are needed. It should then be possible to determine the true molecular weight of the polypeptide chain(s) and the possibility that the gonadotrophic activity associated with proteins of $M_{\mathrm{r}} 80-100000$ is due to a high molecular weight variant of the marmoset CG can then be explored.

Data from radioimmunoassays in which the cross-reactions of gonadotrophins from a variety of primate species have been investigated (Chen \& Hodgen, 1976; Hodgen, 1980) indicate that the degree of binding of CG from the different species is dependent upon the antiserum being used. Chen \& Hodgen (1976) reported that, unlike those of the chimpanzee and gorilla, the CG of the common marmoset was not recognized by antibodies raised against the $\beta$-subunit or $\mathrm{C}$-terminal peptide of human CG. These findings are consistent with those gathered during the present study when it was found that antibodies raised against human CG bind poorly to marmoset CG (and vice versa) when tested by ELISA or by incubation with CG following transfer to nitrocellulose paper (P. T. K. Saunders, unpublished observations).

Hodgen (1980) drew attention to the problems of interpretation and comparison between species that arise when data from bioassays, radioreceptor assays and radioimmunoassays are used. In view of the reportedly low cross-reaction of marmoset CG with anti-human CG antisera, which were subsequently borne out by our own findings, all samples were screened with the mouse testicular bioassay. In our studies the specific biological activity of the CG recovered from the culture media or plasmas was increased up to 20 -fold by the purification procedure used, but the most active samples of CG from culture fluids were only $2-4$ i.u./mg total protein. Hobson \& Wide (1972) reported that $C G$ extracted from the term placentas of 2 marmosets had biological activities in the mouse uterus bioassay of $1.5 \mathrm{i}$.u./g wet weight tissue which was 15 -30-fold less than levels in the term human placenta and 10-fold less than that of the rhesus monkey. The biological activity of the partly purified marmoset CG was low compared to that reported for samples of CG purified from human pregnancy urine. Canfield \& Morgan (1973) and Morgan et al. (1974) have isolated human CG with activity of 12-15000 i.u./mg as determined in the rat ventral-prostate weight assay.

Studies with human CG have demonstrated that biological potency is profoundly influenced by modifications to the carbohydrate side chains (Chen et al., 1982). In addition, some CG secreted by normal tissues and transformed cell lines has lower biological activity than placental $\mathrm{CG}$ and was found to possess an oligosaccharide structure different from that of the hormone active during pregnancy (Ashitaka et al., 1972; Cole \& Hussa, 1984). It is possible that the structure of the oligosaccharide marmoset $C G$ secreted in vitro is of a type not readily recognized by the Leydig cell receptor, resulting in a low estimate of biological activity (see Chen et al., 1982), or that contaminants not detected by PAGE remain in the sample.

In this preliminary report, the partial purification of marmoset $\mathrm{CG}$ has highlighted both the similarities and differences between the glycoprotein found in this species and in the human. Additional work is needed to eliminate any remaining contaminants, verify the bioassay data and confirm that the glycoprotein is made up of subunits.

We thank Anthea Hardwick and Margaret Miller for technical assistance. These studies were supported by programme grants (to J.P.H.) from the Medical Research Council (U.K.) and the Agriculture and Food Research Council (U.K.). 


\section{References}

Ahmed, A.G. \& Klopper, A. (1983) Diagnosis of early pregnancy by assay of placental proteins. $\mathrm{Br} . J$. Obstet. Gynaecol. 90, 604-611.

Ashitaka, Y., Mochizuki, M. \& Tojo, S. (1972) Purification and properties of chorionic gonadotropin from the trophoblastic tissue of hydatidiform mole. Endocrinology 90, 609-617.

Baenziger, J.U. \& Fiete, D. (1979) Structural determinants of Concanavalin A specificity for oligosacchardies. $J$. biol. Chem. 254, 2400-2407.

Birken, S. \& Canfield, R.E. (1980) Chemistry and immunochemistry of human chorionic gonadotropin. In Chorionic Gonadotropin, pp. 65-88. Ed. S. J. Segal. Plenum Press, New York.

Canfield, R.E. \& Morgan, F.J. (1973) Human chorionic gonadotropin (HCG). In Methods in Investigative and Diagnostic Endocrinology, 2B, pp. 727-733. Eds S. A. Berson \& R. S. Yallow. North Holland, Amsterdam.

Canfield, R.E., Morgan, F.J., Kammerman, S., Bell, J.J. \& Agosto, G.M. (1971) Studies of human chorionic gonadotrophin. Recent Prog. Horm. Res. 27, 121-164.

Catt, K.J., Dufau, M.L. \& Vaitukaitis, J.L. (1975) Appearance of hCG in pregnancy plasma following the initiation of implantation of the blastocyst. $J$. clin. Endocr. Metab 40, 537-540.

Chambers, P.L. \& Hearn, J.P. (1979) Peripheral plasma levels of progesterone, oestradiol-17 $\beta$, oestrone, testosterone, androstenedione and chorionic gonadotrophin during pregnancy in the marmoset monkey, Callithrix jacchus. J. Reprod Fert. 56, 23-32.

Chen, H.-C. \& Hodgen, G.D. (1976) Primate chorionic gonadotropins: antigenic similarities to the unique carboxyl-terminal peptide of hCG $\beta$ subunit. $J$. clin. Endocr. Metab. 43, 1414-1420.

Chen, H-C., Shimohigashi, Y., Dufau, M.L. \& Catt, K.J. (1982) Characterisation and biological properties of chemically deglycosylated human chorionic gonadotropin. J. biol. Chem 257, 14446-14452.

Cole, L.A. \& Hussa, R.O. (1984) The carbohydrate on human chorionic gonadotropin produced by cancer cells. Adv. exp. Med. Biol. 176, 245-270.

Cummings, R.D. \& Kornfeld, S. (1982) Fractionation of asparagine-linked oligosaccharides by serial lectinagarose affinity chromatography. J. biol. Chem. 257, 11235-11240.

Harlow, C.R., Hearn, J.P. \& Hodges, J.K. (1984) Ovulation in the marmoset monkey: endocrinology, prediction and detection. $J$. Endocr. 103, 17-24.

Hay, D.L. (1985) Discordant and variable production of human chorionic gonadotropin and its free $\alpha$ - and $\beta$-subunits in early pregnancy. J. clin. Endocr. Metab. 61, 1195-1200.

Hearn, J.P. (1979) Immunological interference with the maternal recognition of pregnancy in primates. In Maternal Recognition of Pregnancy (Ciba Fdn Symp 64), pp. 353-375. Ed. J. Whelan. Excerpta Medica, Amsterdam.

Hearn, J.P. (1983) The marmoset monkey, Callithrix jacchus. In Reproduction in New World Primates, pp. 181-215. Ed. J. P. Hearn. MTP Press, Lancaster.

Hobson, B.M. \& Wide, L. (1972) A comparison between chorionic gonadotrophins extracted from human, rhesus monkey and marmoset placentae. J. Endocr. 55, 363-368.

Hodgen, G.D. (1980) Patterns of secretion and antigenic similarities among primate chorionic gonadotropins: significance in fertility research. In Chorionic Gonadotropin, pp. 53-63. Ed. S. J. Segal. Plenum Press, New York.

Hodgen, G.D., Wolfe, L.G., Ogden, J.D., Adams, M.R., Descalzi, C.C. \& Hildebrand, D.F. (1976) Diagnosis of pregnancy in marmosets: hemagglutination inhibition test and radioimmunoassay for urinary chorionic gonadotropin. Lab. Anim. Sci. 26, 224-228.

Kessler, M.J., Mise, T., Ghai, R.D. \& Bahl, O.P., (1979a) Structure and location of the O-glycosidic carbohydrate units of human chorionic gonadotropin. $J$. biol. Chem. 254, 7809-7811.

Kessler, M.J., Reddy, M.S., Shah, R.H. \& Bahl, O.P. (1979b) Structures of $N$-glycosidic carbohydrate units of human chorionic gonadotropin. J. biol. Chem. 254, 7901-7906.

Knobil, E. (1973) On the regulation of the primate corpus luteum. Biol. Reprod. 8, 246-258.

Landesman, R. \& Saxena, B.B. (1976) Results of the first 1000 radioreceptor assays for the determination of human chorionic gonadotropin. Fert. Steril. 27, 357-361.

Maruo, T., Segal, S.J. \& Kiode, S.S. (1980) Large molecular species of human chorionic gonadotropin. In Chorionic Gonadotropin, pp. 178-197. Ed. S. J. Segal. Plenum Press, New York.

Morgan, F.J., Canfield, R.E., Vaitukaitis, J.L. \& Ross, G.T. (1974) Properties of the subunits of human chorionic gonadotropin. Endocrinology 94, 16011606.

Peters, B.P., Brooks, M., Hartle, R.J., Krzesicki, R.F., Peresi, F. \& Ruddon, R.W. (1983) The use of drugs to dissect the pathway for secretion of the glycoprotein chorionic gonadotropin by cultured human trophoblast cells. J. biol. Chem. 258, 14505-14515.

Roberts, R.M., Baumbach, G.A., Buhi, W.C., Denny, J.B., Fitzgerald, L.A., Babelyn, S.F. \& Horst, M.N. (1984) Analysis of membrane polypeptides by two dimensional electrophoresis. In Molecular and Cellular Characterization of Membrane Receptors, pp. 61-113. Eds J. C. Venter \& L. Harrison. Alan R. Liss \& Co., New York.

Summers, P.M., Taylor, C.T. \& Hearn, J.P. (1987) Characteristics of trophoblastic tissue derived from in vitro culture of embryos of the Common marmoset. Placenta (in press).

Van Damme, M-P., Robertson, D.M. \& Diczfalusy, E. (1974) An improved in vitro bioassay method for measuring lutienizing hormone (LH) activity using mouse Leydig cell preparations. Acta endocr., Copenh. 77, 655-671.

Warren, L., Blithe, D.L. \& Cossu, G. (1982) Variation of the carbohydrates of glycoproteins of cells growing on different surfaces. J. cell. Physiol. 113, 17-22. 